\title{
National and European Identity
}

\section{Introduction}

This article considers the attempt by the European Union to create a common European identity. Its point of departure is the argument made by Ben Wellings and Ben Power (2015) , 'Euro-myth: nationalism, war and the legitimacy of the European Union', in National Identities. Their case was prompted by an article of Montserrat Guibernau (2011), 'The birth of a United Europe: on why the EU has generated a "non-emotional" identity", in Nations and Nationalism. Wellings and Power argue, contrary to Guibernau, that the EU has acquired more than pragmatic support amongst European peoples, based on the common pursuit of prosperity - a 'non-emotional' identity'. In fact, they argue that there is reason to think that European nationalism has emerged with, like all nationalisms, an emotional dimension.

The article begins with an assessment of the cases made by these authors. Their arguments serve as co-ordinates for the wider examination of European identity I then undertake. This consists of an overview of the history from the mid 1970s to the present day of the European Economic Community, subsequently the European Union, in relation to this question. The documentary evidence I examine suggests that the supranational ambitions of, in particular, the Commission have been constrained by the wider intergovernmentalism of the EU. Despite this, the most authoritative data on European identity I consider next, the Eurobarometer survey (Commission 2018), suggests an appreciable level of European belonging. In order to understand European belonging, I finally assess the gestation of Europeanism in respect to citizenship, values and everyday life. 
The article is one of several deliberations (see Spieling, 1999; Cram, 2009; Antonsich, 2009; Della Sala, 2016) by students of nations and nationalism on the EU and national identity. Clearly it is a timely moment to do so. After the UK voted to leave the EU on June $23^{\text {rd }}$, 2016 , there was speculation that the result would start the collapse of the organisation. However, subsequent elections in key EU states did not see the success predicted for populist Eurosceptic parties. Simultaneously, the most recent EU polling (Eurobarometer 2018) demonstrates a modest growth in identification with the EU - even in BREXIT Britain. Yet the centrifugal strains of nationalisms within the EU, at the time of writing between two of its founding member states, France and Italy, are self-evident.

\section{The cases of Guibernau and Power and Wellings}

Guibernau (2011, p.302) says at the beginning of her article that it is possible to distinguish a European identity from the European integration associated with the EU. Some figures, notably Margaret Thatcher (Thatcher) claimed in her famous 1988 Bruges speech that there is a definite difference as Europe was not the creation of the Treaty of Rome (the 1957 founding of the European Economic Community) nor the property of any one group or institution. The EU (Commission 2018) itself makes an empirical division between EU and

European loyalties in its Eurobarometer citizenship surveys. ${ }^{i}$ However, separating the two is impractical in contemporary discussion of the subject and I generally make no further delineation.

Guibernau's case rests on the formative role of a group of European intellectuals - Jean Monet and Robert Schuman in France, Konrad Adenauer in West Germany, Alcide De Gasperi and Altiero Spinelli in Italy and Paul-Henri Spaak in Belgium - in the making of 
European institutions after 1945, i.e. the European Coal and Steel Community in 1951 and the EEC six years later, comprising Belgium, France, Italy, Luxembourg, the Netherlands, and West Germany. Despite differences in the political backgrounds of these figures, (p.306) 'architects of a united Europe', they were at one in their determination to end the antagonisms that had wrought catastrophic wars in their continent during the first half of the twentieth century.

Guibernau acknowledges the historic achievement of the EU's founders in creating an institutionally integrated Europe. However, the question of whether a European identity has emerged to co-exist with or even replace national identities is very different. She argues that this has not happened, was never likely to and will not do so in the foreseeable future. The most basic reason for this is that the EU is not a nation-state, let alone a nation, and therefore does not command the allegiance of the various peoples who comprise it. Conscious of this, Monnet et al never intended to build a common European identity akin to a national one. Rather, their aim was to build a new type of political entity with a different kind of legitimation. It was one created and run by European elites to integrate states and peoples, most importantly France and Germany, through trade and development. From the outset, the EU has sought greater productivity, efficiency and economic growth, not the satisfactions of emotive passions. The corollary to this is that as support for the EU is instrumental, it is dependent on rising prosperity.

Guibernau argues that even if some of the EU's founding fathers had loftier federal ambitions, they were constrained by a realist entrenchment within their states and an ambivalence about over committing to an organisation that might in the longer term undercut their domestic support. To this end, she references (2011, p. 311) Milward's 
(1999) influential argument than the objective of the six original signatories of the Treaty of Rome was not an overarching super state, but an intergovernmental rescue of the nation state. The outcome (Guibernau, 2011, p. 313) was that there was no serious attempt by the originators to 'damp down the fires of nationalism' by 'mobilising the people in favour of a united Europe'. From this, she draws (p. 314) the conclusion that 'the flames of nationalism have not been extinguished. At the dawn of the twenty-first century, national identity remains much more powerful than the still incipient "non-emotional" European identity".

The clarity of Guibernau's case rests on two lacunae. First, she gives a selective overview of the motivations of the EU's founding fathers. A wider reading by Vanke (2007) shows that a discernible Europeanism existed amongst the luminaries, not simply a Saint Simonian rationalism. And this was not simply a matter of personal sentiment. The first line of the Treaty of Rome undertakes to 'lay the foundations for an ever-closer union among the peoples of Europe'. This formative idealism of the EU clearly sets it apart from other regional organisations - NAFTA, ASEAN, MERCOSUR - and is one strand in its subsequent development and undetermined future. Second, Guibernau does not examine the subsequent history of the EU, specifically the attempts of the organisation to create a European identity or the empirical evidence for its existence. These are subjects that Wellings and Power (2016) do take up in their rejoinder.

The case of Wellings and Power $(2015$, p.3) stems from the claim that nationalism should be 'understood as the legitimisation of a particular location (polity) of sovereignty'. This theoretical proposition is based on original readings of classic studies of nationalism, primarily those of Gellner and Anderson, also the writings of Billig, Breuilly, Özkirimli and Hearn. ${ }^{\text {ii }}$ This enables their argument $(2015$, p. 5) that a European nationalism has emerged 
to justify the sovereignty of the EU that now spreads 'thinly but broadly across its intergovernmental and supranational layers and pillars'. Wellings and Power do not say that a European nationalism has succeeded in superseding the allegiance of nation states. Rather, they point out that Eurobarometer polling shows that European identification is impressively high. It contains, moreover, an emotional dimension, one there from the outset in the impassioned pursuit of peace by its founders. In the face of protracted crisis over the last twelve years, the EU has extolled its crowning achievement of peace amongst its peoples. The remembrances of war not as heroic sacrifice, but human catastrophe fits within a wider 'memory boom' in European societies. The Commission highlighted this in its 2007 commemorations of the Treaty of Rome. Since then, notably after the collapse of the Greek economy in 2010, this accomplishment has been reiterated. Power and Wellings ( $p$. 16) concede that is a 'somewhat negative founding myth' as the message only amounts to 'no matter how bad things are now, they could be worse'.

One immediate response to the argument of Wellings and Power is that narratives that rest on the appeal of a negative can come to appear desperate and weak - desperately weak. The self-justification of Federal Yugoslavia in its latter years that unity had least prevented ethnic war amongst its republics, became vulnerable to the colour of rival nationalisms that promised much, if delivered little (Jović, 2009). This aside, our task remains to examine the attempts by the EU to create a European identity. We do so in the light of the contrasting understandings of Guibernau and Wellings and Power: respectively, that European identity has only an instrumental basis; that the EU has unwittingly created its own emotive nationalism to justify its existence. 


\section{The EU and European Identity}

The first point to make is that nobody connected to the EU has directly called for the creation of a European nation with its own nationalism. As Guibernau argues, the motivation of its founders was to shackle nationalism. Monnet (Duchêne, 1994, p.401) was emphatic: 'We should not create a nation Europe instead of a nation France'. The one direct form of what should be termed European nationalism came from a rather different, if contemporaneous, source: the remnants of fascist movements. The idea (Judt, 2007, p.154) was not derived from any historic ideal, but in the war time perception of some fascists Pierre Pucheu of Vichy France, Albert Speer of Nazi Germany - that the sweep of the Wehrmacht across the continent presaged an amalgamated, borderless Europe. It was resurrected in 1946-7 by Oswald Mosley (Dorril, 2007, pp. 607-24) the pre-war leader of the British Union of Fascists. He favoured a comprehensive European federation as a bulwark of Caucasian civilization between the communism of the USSR and the free market capitalism of the USA. To this end, he formed the European Social Movement in 1950 and then the National Party of Europe in 1962. From Paris in his later years, Mosley backed the development of the EEC as a precursor to a new fascist European order. However, his ideas won only a little support on the far right in Britain, Germany, Italy and elsewhere. The point is not only of historical interest. The recent coming together (Shotter, 2018) of far-right groups across the continent could be seen as an authentic echo of European nationalism. Not that contemporary fascists view the EU favourably. On the contrary, their hatred of it is itself a form of unity, as indicated by the burning of its blue flag at demonstrations. ${ }^{\mathrm{iii}}$

Rather, the new (in Duchêne, 1994, p.401) institutional 'pillars of civilization' that Monnet et al wanted to establish through European union were supranational ones. So, the issue is 
the degree to which the EU has attempted to define and project an identity that will justify its existence in a federal quest. Now it is generally unwise (Cini, 2007) to see the history of the EU as a long march towards greater federalism as it supersedes its coeval of intergovernmentalism. A better starting point is to view this tension as one of several within the EU. ${ }^{\text {iv }}$ Looking over its sixty-one-year history, it is evident that the express attempt to define and project a European identity was most evident when the federalist argument, the attempt to establish the ascendency of European union, has been to the fore. In some accounts (Scott-Smith, 2003) this was a short period between the mid 1980s and early 1990s when the objectives of most members of the Council of Ministers matched the ambitions of the Commission. Conversely, when intergovernmentalism has held sway, as it has for much of the EU's history, express attempts to further a European identity are less evident. This point is distinct from the rise of EU economic governance following economic and monetary union as this is less reliant on evocations of a common identity. In this instance, legitimation, resting on a supposed elite level competence, is more confined (Barker, 2001; Beetham \& Lord, 1998) to an inter-governmental level.

Whatever the idealism of the founders of the EU, they had little interest in promoting a European narrative amongst the peoples of their nations. Rather, as indicated above, their aim was to establish institutions and laws to integrate European nation-states. In so far as there was consideration of the likely political outcome of economic integration in the early years of the EEC, the functionalism of Ernst Haas (1958) was influential, i.e. it would occur as a (Holland, 1994) 'spillover'. That this had not happened was apparent to European leaders in the early 1970s as the economic outlook deteriorated following the long post war boom. It is within the context of attempts to breathe life into the EEC in this period by pushing 
towards European integration that the first distinctly cultural policy proposals were made. At the EU heads of state meeting in Paris in December 1974 Leo Tindemans, the Belgium PM, was asked to draw up a report on how the term 'European Union' might be interpreted. His findings were presented to a European Council Meeting eighteen months later.

Tindeman's report (Communities, 1975) opened with the declaration that, 'The aim of the EU is to overcome the age-old conflicts which are often artificially maintained between nation states... and to build a more humane society in which the accent will be factors uniting us more than on those dividing us'. Further, (p.12) 'no one wants to see a technocratic Europe. European Union must be experienced by the citizen in his daily life'. To this end, he made various policy proposals, notably for direct elections for the European Parliament. In respect to European citizenship and culture, he advised greater freedom of movement, extended individual rights, student exchanges, the collaboration of national media organisations and the establishment of a European Foundation. He also (p.26) recommended, but did not define, the adoption of 'concrete manifestations of European solidarity by means of external signs discernible in everyday life'.

Although his report generated little enthusiasm, it did place cultural integration on the European agenda over the next two decades. As economies recovered from the doldrums of the 1970s, the EEC acquired a self confidence that saw the 1987 Single European Act and the 1992 Maastricht Treaty. Declarations of cultural unity in this period were matched by measures intended to make European union more appealing to the peoples of its member states (disputed by Britain and Denmark, see Theiler, 2005). The Solemn Declaration on European Union of June 1983 (Communities, 1983, p.25), signed by the ten heads of state, referred to, 'A common destiny and the wish to affirm the European identity [the first use of 
the term] through commitment to progress towards an ever-closer union among the peoples and Member States of the European Community'. Its practical recommendations (including a European University in Florence) were designed (p.28) to 'improve knowledge of European member states of the Community and of information on Europe to promote European awareness'. This was followed by the establishment of the Committee for a People's Europe (Commission, 1985), the Adonnino Committee, by the European Council in June 1984. The Committee's proposals were presented and adopted by the Council the following year.

The cultural dimension (p. 18) was framed as 'responding to the expectations of the people of Europe' by 'adopting measures to strengthen and promote its identity and its image both for its citizens and for the rest of the world'. In respect to European citizenship, it proposed the abolition of all barriers to cross border movement: Europe sans frontières. In relation to culture, it recommended a European passport, a European flag (basically that of the Council of Europe), an anthem (Beethoven's Ode to Joy), a European Day (May $9^{\text {th }}$ ), the strengthening of a European dimension in school education through common text books and the production of European wide stamps that (p. 29) highlight 'underlying values' or events in Community history ('like the accession of Spain and Portugal'). The passport, flag, anthem and European Day were subsequently introduced.

Notwithstanding some qualifications about the European flag not 'affecting the use of national flags', the Adonnino Committee is the most 'nation building like' document in the EU's history. Biegon (2013) claims that the period 1985-89 was the highpoint in a European identity narrative that, for a time, succeeded in eclipsing a functional narrative of EU integration. Besides Adonnino's recommendations, she points (p.205) to appeals of the 
then Commission President, Jacques Delors, for Europe to find 'a little more soul' and to his allusions to the superiority of European civilization compared to that of the US. Scott-Smith $(2003$, p.270) argues that this trajectory of European identity reached an apex with the Commission's endorsement of Jean-Baptiste Duroselle's Europe: A History of its People published in 1990. For Delors, the book's pre-destined history (the stuff of nationalist historiography) acted as background music for 'the next stage of integration that was to be thrashed out in Maastricht'. But the Commission's proposals were not backed by any legal mandate for a European cultural policy, resulting in a 'grey zone' in which cultural initiatives had only an economic justification and limited funding.

If the EU's trajectory towards a European identity flat lined after 1990, the Maastricht Treaty of European Union of 1992 (Commission, 1992) is generally interpreted as establishing a contrary principle. The Treaty begins (p.3) by stating that the heads of member states wish to 'deepen the solidarity between their peoples', but continues 'while respecting their history, their culture and their traditions'. In the section on culture the formulation is reversed. The given aim (p.48) is the flowering of the cultures (plural) of the member states to respect 'their national and regional diversity', whilst 'at the same time bringing the common cultural heritage to the fore'. In practical terms, there are several proposals designed to further European understanding through collaboration and exchange, but not to further a common culture. The term 'identity' is absent. Moreover, Maastricht enshrined (p.4) the principle of subsidiarity which meant that the Commission was prevented from acting on its own initiative in this area through directives and even the Council could not proceed without unanimity. Thus, according to the European taskforce on Culture and Development, $(1997$, p.37) 'Article 128 is widely regarded as much as a device 
to control Commission activity in this sector as encourage it, some countries believing that cultural action at a European level could threaten the independence of national cultural policies'.

European cultural policy did not subsequently disappear, but further initiatives depended upon the will of the member states who had established the pre-eminence of their national cultures. Simultaneously, there was to be no distortion of the market in respect to cultural subsidy. Five years later the Amsterdam Treaty (Communities, 1997) brought amendments to further underline this priority. Article (p.39) 128(4) now read, 'The Community shall take cultural aspects into account in its action under other provisions of this Treaty, in particular in order to respect and to promote the diversity of its cultures' (my italics).

Notwithstanding this shift away from a common European culture and identity in negotiations and treaties, Cris Shore's (2000) study of EU cultural politics in this period, Building Europe, finds that this was precisely what was afoot - one of the few studies of the Commission based on fieldwork in Brussels. The polemical tone of the book, possibly owing something to his father, Peter Shore, the Eurosceptic Labour MP and intellectual, is posted (p.xi) in the preface in his description of the aversion of European studies to questioning EU integration as 'unfounded, ignorant and intellectually dishonest'. Shore proceeds by scrutinising 'the panoply of cultural devices and techniques being deployed by EU policy professionals to turn the "European idea" into a reality". Far from there being any shift away from culture and identity, he found that the phrase "Europe on the move" - which is also the title of European Commission public information booklets - summed up the feeling of optimism that I encountered in Brussels'. In his research interviews, Shore (p. 26) spoke to officials, 'agents of European consciousness', who were open about their role in making 
peoples (p.22) 'more aware of their European identity'. They had a (p. 32) 'vanguard role' like the intellectuals who invented the traditions of nineteenth century European nationalisms. In fact, their intent (p. 18) with Europe was akin to that of Massimo d'Azeglio following Italian unification in 1870: 'We have created Italy, now we must create the Italians'.

Shore's study (p.26) extended to 'all those actors, actions, artefacts, bodies, institutions, policies and representations which, singularly or collectively, help engender awareness and promote acceptance of "the European idea"'. He sees the single market, the Euro, the metric system for weights and measures and the proliferation of EC laws and regulations, educational exchanges, town-twinning, invented European traditions, EU historiography and the harmonisation of European statistics by the Eurostat office as 'contributing in some way or another to the way people perceive and experience Europe in relation to themselves'. This (p.1) was 'driven largely by political imperatives, particularly the need to endow the EU's institutions and emerging system of transnational governance with legitimacy'. Its aim (p.29) was 'to create a new kind of post-national political and cultural order that will supersede the nation-state'.

Shore suggests that Europe building lost momentum as the 1990s wore on given the indifference and scepticism of European peoples, as evidenced by referenda results and Eurobarometer polling. In part (p.64), that was because the post nationalist symbols appeared as cheap 'imitations of nationalist iconography'. As a result, they failed to win for the EU 'the title deeds upon which national loyalties and allegiances are claimed'. But the bid for hearts and minds was never likely to succeed as Europe simply does not exist in a form analogous to a nation. Thus (p.32) the 'absence of a sense of common historical 
experience or shared memory, remains a crucial factor in explaining the difficulty in integrating Europeans'. Shore cites (p.16) Smith on the artificiality of a European identity compared to that of nations proper, a similar point to Guibernau (2011). So, whilst (p.219) the EU might have succeeded in 'meshing together Europe's political and financial elite' in a new supranational state formation, he is incredulous of a wider post-nationalist European political order. In fact, greater federal integration will only trigger movements of archaic compensation given EU homogeneity - what is now generally referred to as 'populism'.

The trouble with this argument, as Dellavalle (2017) has recently pointed out in discussion of national polities as opposed to the 'no demos' of Europe, is that it rests on a questionable dichotomy. At times, Shore almost contrasts the 'real' invented traditions of nation building with the 'fake' invented traditions of European building, when the point about this very process is that it involves fabrication. As Dellavalle (2017, p.29) says, 'A sense of collective identity is not the result of some "ethnic origin of nations", but a highly mediated cultural construct which is based on political decisions'. Crucial in nationalising the masses is the role of the state. The European state, the EU, lacks the resources to undertake such a task with a salariat a fraction of a European city and a budget roughly one per cent of its members' GDP. In any case, its inherent make-up as an organisation of nation-states limits the pursuit of an alternative, wider identity - as the Maastricht Treaty established.

Other writers have detected a changed discourse emerging in the 1990s. Biegon (2013, p. 206) notes that as early as 1990, prompted by the collapse of Stalinist regimes to the East and talk of the 'democratic deficit', a changed narrative of Europe arose in which the new buzzwords of 'citizenship', 'transparency', 'subsidiarity' and 'communication', above all 'legitimacy' were much used. Scott-Smith (2003, p. 271) cites an attempt by a Dutch 
sociologist, Abram de Swaan, in 2000 to interest the Commission in a research project into 'the reasons for the absence of a European cultural elite (read: "European intellectuals developing the European idea") and what could be done about it' is indicative of how wary officials in Brussels had become of this subject. De Swann received the tart reply that the EU avoids cultural questions such as this, particularly those 'relating to elites'.

In a subsequent article, Shore (2011) noted that there was a marked shift at the end of the 1990s in, in particular, Commission evocations of European integration. This was caused by the fallout from the March 1999 corruption scandal which saw the mass resignation of commissioners. In the aftermath, the Commission embarked on a new phase in the history of European integration. This involved a legitimation of 'European governance'.

Governance has the advantage, according to Shore (2011, p.296), of appearing 'more inclusive, pluralistic, consensual and less hierarchical' as the EU appears as the manager of the 'shared goals' of European peoples. As implicitly governance is on behalf of the people, it is less reliant on democratic legitimation than more traditional forms of government. In fact, its 'postmodern' billing obscures the neo-liberal direction that the EU now follows, the latest manifestation (p.291) of its cynical, 'bread and circuses' politics.

Evocations of a shared identity and common future did not completely disappear. Shore $(2012$, p.5) notes how the Euro was hailed in 2001 as a 'symbol of the future integration of 300 million people'. Such false optimism aside, the tenor of EU treaties remained the same as Maastricht. So, whilst clause 167:2 of the 2006 Lisbon Treaty (Democracy, 2009, p. 120) says the EU (now comprising a disparate twenty-five states following the enlargement of 2004) will support the 'improvement of the knowledge and dissemination of the culture and history of the European peoples', 167:3 states it will 'respect and to promote the diversity of 
its cultures'. The role of the EU in the making of a European culture does not disappear from other documents in this period. The 2007 Commission (2007, p.2) European Agenda for Culture in a Globalizing World, speaks of 'forging common understanding and rules which have guaranteed peace, stability, prosperity and solidarity'. But that comes after the assertion, 'The originality and success of the European Union is in its ability to respect Member States' varied and intertwined history, languages and cultures'.

More importantly, studies of EU cultural policy since 2000 reveal that in practice the diversity aspect has been to the fore. Sassatelli's $(2008, p .233)$ examination of the Capital of Culture programme says that EU attempts at 'mimicking the nation' in proclamations of European unity were always rather half-hearted. Furthermore, the organisers of successful cities in the programme have exceeded the EU's diversity remit in portraying the particularity of the municipality, rather than the wider nation it is part of. Littoz-Monnet (2012) finds an explicitly commercial aspect to EU cultural policies stemming from the Lisbon Treaty, i.e. how 'cultural and creative industries' are viewed in terms of growth and jobs.

As one might expect, the most recent Commission (2017a) offering on the future of Europe has a cautious tone. It acknowledges in the introduction that too many Europeans 'consider the Union as either too distant or too interfering in their day-to-day lives' and think that 'the EU fell short of their expectations as it struggled with its worst financial, economic and social crisis in post-war history'. The fundamental role of the EU in maintaining peace is extolled, pace Wellings and Power (2015). However, it acknowledges that this is not something (2017a, p.6) 'all of today's Europeans can relate to in the same way as their parents or grandparents'. The only mention of culture is in relation to Europe's diversity, 
'The EU is now the place where Europeans can enjoy a unique diversity of culture, ideas and traditions in a Union covering four million square kilometres'. A deeper federalism is outlined (p.24) as one amongst five possible futures, but this seems a perfunctory exercise given the risk of 'alienating parts of society which feel that the EU lacks legitimacy or has taken too much power away from national authorities'. Jean-Paul Juncker's (Commission 2016) speech to the European Parliament the year before spelt out the obstacles facing Europe integration. 'We are not the United States of Europe', he declared. 'Our European Union is much more complex. And ignoring this complexity would be a mistake that would lead us to the wrong solutions'. Juncker's lack of confidence matches the understated coverage of the EU's website (European Union, 2019) of its history and symbols.

All of this is not to suggest that the actual of power of the EU has weakened. In important respects, notably economic governance (Fromage \& Brink, 2018) it has strengthened - and without even the pretence of democratic underpinning. Enhanced power has been realised within the reality of economic and monetary union as the disciplining of Greece and a wider financial austerity demonstrates. To some degree and for reasons we do not have the opportunity to explore, this has been more to do with the ability of a particular power within the EU, Germany, to pursue beggar thy neighbour economic policies than a consensual drift. More recently, ambitious plans for a European army have been advanced by Macron, the French President, though the rationale for this was more one of realpolitik than European unity. The key point for our purposes is that a formal, certainly a singular, pursuit of a European identity based on the assertion of a shared culture has faded in recent history. As an unqualified aim this existed only for a short period prior to the Maastricht Treaty of 1992 - and even then it was contentious. Subsequently, the EU has been more 
inclined to stress its role in maintaining national diversity amongst its members. In this respect, history confirms the theoretical case of Guibernau. However, simultaneously there has been the growth of Europeanism, a development identified by Wellings and Power. Before discussing Europeanism, it is first appropriate to look at how European the people of EU countries feel about the organisation. By doing so we make a limited but significant empirical assessment of how successful the EU has been in forging a common identity.

\section{Eurobarometer Surveys and European Identity}

The annual Eurobarometer surveys that began in 1974 are in themselves part of the concern with European identity. They are not complete guides to European attitudes, but their findings are of interest. The most recent one (Commission, 2018), based on over 27,000 respondents, was published in the Spring of 2018. The results show that feelings of national identification (varying enormously) with country are approximately twice those to the European Union. Some $93 \%$ feel attached, $57 \%$ very attached, to their nation, whilst $56 \%$ feel attached to the EU with only $14 \%$ very attached. This is the most important finding for our purposes: confirmation of Guibernau's argument of the strength national allegiance compared to a European one. However, the level of European, specifically EU, identification gives some endorsement of the case of Power and Wellings of a parallel level of allegiance vis-à-vis the organisation, if not their claims of a fully-fledged nationalism. In light of this, it is interesting to briefly consider relevant findings of the Barometer survey. In doing, there is inevitable elision in the formal distinction between the development of a sense of belonging and pragmatic support based on the perceived benefits of EU membership. 
The survey (p. 20) found that 'the free movement of people, goods and services within the $E U^{\prime}$ is seen as its greatest achievement in twenty member states, within a range of $80 \%$ (Lithuania) to $40 \%$ (France). 'Peace among the Member States of the EU' is seen as the most important in seven, notably France and Germany. In joint third place student exchange programmes such as ERASMUS were mentioned most frequently. In only one country in Europe, Ireland, did the Euro receive majority support in polling. The most positive perceptions of Europeans (p.29) relate to citizenship. A majority of people in all EU states feel themselves citizens of the European Union (as well as being national) for the first time since polling begun. This varies between $87 \%$ in Ireland and $51 \%$ in Bulgaria and Greece, giving a proportion of $70 \%$ amongst the twenty-eight.

An attribute of the survey is that it reveals (p.16) that identification with the EU is strongly influenced by social class. For instance, a majority (66\%) of Europeans who studied up to the age of 20 and beyond feel attached to the EU, compared with only a minority of those who left school at the age of 15 or earlier (43\%). The impact of age on opinion is easily summarized: the younger the age group the stronger the identification with the EU. The affect is not as great as might be imagined: $61 \%$ of $15-24$ year olds say they are attached to Europe, compared to $52 \%$ of those over 55 . The influence of gender meanwhile is insignificant.

The accusation that the EU is primarily an institution of elites by elites is well known. Giandomenico Majone (2002, p. 7) argues that no 'Europeanization of the masses' has taken place that is even remotely comparable to that of the 'nationalization of the masses'. And class is commonplace in explaining the high EU leave vote in poorer, de-industrialised parts of Britain. However, even allowing for a class and demographic profile, the empirical 
indications of identification with the EU show that it is not confined to networked elites who have drawn the principal benefits. To begin to understand why this is the case, to explore the limited but significant success of the EU at this level, we must finally consider the issue of Europeanism.

\section{Europeanism}

Europeanism is not the most eloquent or precise term, but it conveys a variety of formal and more informal developments (for its various meanings see Olsen, 2002). In the following discussion, I break it down it into three components to provide clarity: as citizenship, as discourse and everyday life. It goes without saying that there are cross overs between them and that Europeanism, whatever it is, does not fully explain support for the EU. That would require a wider review of the perceived practical benefits of the EU, something well beyond the scope of this article.

The formal attributes of European citizenship for EU members are the right of free movement within the Union, the right to vote and stand in EU elections and the right to diplomatic representation by a fellow EU state whilst in a third country. Human rights are set out in the Charter of Fundamental Rights of the EU under the ultimate jurisdiction of the Court of Justice of the European Union.

The development of European citizenship has been a piecemeal process. The most valued aspect and its key dynamic, freedom of movement, goes all the way back to the 1957 Treaty of Rome. In a direct form, the 1992 Maastricht Treaty was key to its institutionalisation. 
Since then, the insistence on the equal rights of EU nationals across the Union, of jus soli rather than just sanguinis in legal terms, has proved contentious in the context of the enlargement of the Union, notably in Britain given the mass migration it has allowed.

Much of the coverage of European citizenship has critically compared it to national citizenship. The central issue (Dellavalle 2017) has been how an entity like the EU, that lacks a central locus of sovereignty through a democratic polity (a 'demos') founded on the principle of nationality, can acquire the loyalty of constituents (citizens) and place obligations, legal and moral, upon them in return for guaranteed rights, a la a nation state. Others (Seeleib-Kaiser, 2018; Ewing, 2015) have pointed to the EU's failure to stand by workers' rights given neoliberal priorities - 'market' not 'social' citizenship. However, for all this, it does seem Europeans generally value the notion of a form of citizenship that extends beyond the confines of their nation states. Moreover, in contrast to a European identity, citizenship it is something that the Commission (2017b) is seeking to accentuate.

The second form of Europeanisation is about what it is to be European, how such an identity is defined. In some (Graziano \& Vink, 2008, p.7) farfetched formulations, it has the potential to 'take root alongside national identities and interests, indeed to inform and shape them' through "identity reconstruction"”. John McCormick (2010, p.217) identifies the following characteristics and values: cosmopolitanism, communitarianism, collective societies, welfarism, sustainable development, a refined family, working to live, criminal rights, secularism and perpetual peace. Unlike others McCormick (2010, p. 1) is highly pessimistic about the possibilities that a European identity can co-exist, let alone replace, national sentiments. He looks to a wider European patriotism to extol Europe's understated achievements since 1945 . This is contrast to the optimism of writers (Guerrina, 2002) who 
thinks that an inclusive European identity is possible in a post-national world, one that does not depend on a racialised exclusion through a 'fortress Europe'. Others (see Abulafia 2016) have looked to the way in which common European values can become integrated into European school education. There is some evidence of this, but overwhelmingly curricula remain under the control of national education ministries.

A third form of Europeanism is harder to define and reference, more inchoate, but no less important because of this. It is one we can term 'the Europeanism of everyday life', something that even Shore $(2000$, p.227) acknowledges - though he says that consumption should not be conflated with identity. Perhaps the most important aspect of this is the relationship between Europeanism and mobility - or mobilities. This involves the ease of moving freely, aided by Wi-Fi, within the EU to work, retire, study (especially ERASMUS) and take short and longer holidays. Such ease of mobility has facilitated a culture in which Europe's young people freely mix in the clubs of Berlin, the bars and coffee shops of Amsterdam and the raves of Ibiza. Out of this milieu relationships and friendships are formed, shorter or longer term, leading to work and residential relocations - and thus further mobility. ${ }^{\text {vi }}$ An obvious objection in relation to the UK is that the lack of immigration control, a usual power of the nation state, loomed large in BREXIT. However, it is likely that even the most nationalist Brit will have some misgivings about having to queue at the 'All other passports' counter at borders, rather than sailing through 'Arrivals from the European Union' under the EU flag, if and when the UK actually leaves the EU. For many in the UK and across the European continent as a whole, especially younger generations, a taken for granted mobility as facilitated by the EU, does appear (Mazzoni et al., 2018) to have furthered a European identity. 


\section{Conclusion}

The enigma of the EU has been there from the outset between a 'moral idea' (Monnet in Holland, p.7) and a functional trading organisation; between federalism and intergovernmentalism. From the mid 1970s there was an attempt to pursue a federalist agenda involving the assertion of an overriding European identity amongst the peoples of its member states. This was not just a matter of rhetoric that nobody noticed as it led to practical measures. However, there was never unanimity in this quest and the wider reservations of national leaders resulted by the time of Maastricht in 1992, the treaty of union, to its downgrading compared to the promotion of national diversity. The call by the Adonnino Committee in 1985 to 'strengthen and promote Europe's identity' are far removed from the defensive communiques of the Commission in 2018.

Paradoxically, the powers of the EU through economic and monetary union have increased. However, these developments have taken place within a differing register, one of governance, of supposed technocratic competence, rather than identity; closer therefore in ideological form to functionalism than, pace Wellings and Power, an incipient nationalism. Simultaneously, however, there has been the gestation of Europeanism. This has resulted in a growing sense of European identity and citizenship. This is not a development that threatens the power of national allegiances. Rather, it should be viewed as a sub development, not a parallel or contrary one. But it is not one that can be neatly categorised as non-emotional either, pace Guibernau - as anyone living in Britain at the present time will testify. 


\section{References}

Abulafia, D. (ed.) (2016) 'European demos': A historical myth? Retrieved December 10, 2018 from

http://web.archive.org/web/20160224115332/http://historiansforbritain.org:80/research/

Antonsich, M. (2009). National Identities in the Age of Globalisation: The case of Western Europe. National Identities, 11(3), 281-299. doi:10.1080/14608940903081085

Barker, R. S. (2001). Legitimating Identities: The self-presentation of rulers and subjects. a Cambridge, UK; Cambridge University Press.

Beetham, D., \& Lord, C. (1998). Legitimacy and the EU. London: Longman.

Biegon, D. (2013). Specifying the arena of possibilities: Post-structuralist narrative analysis and the European commission's legitimation strategies. Jcms-Journal of Common Market Studies 51(2), 194-211. doi:10.1111/j.1468-5965.2012.02310.x

Burgess, M. (2000). Federalism and European union: The Building of Europe, 1950-2000. London: Routledge.

Cini, M. (2007). European Union Politics (2nd ed.). Oxford: Oxford University Press.

Commission (1992) Treaty on European Union. Retrieved on December 3, 2018 from https://europa.eu/europeanunion/sites/europaeu/files/docs/body/treaty_on_european_union_en.pdf 
Commission, European (2007) European Agenda for Culture in a Globalizing World.

Retrieved on December 10, 2018 from https://eur-

lex.europa.eu/LexUriServ/LexUriServ.do?uri=COM:2007:0242:FIN:EN:PDF

Commission, European (2016) State of the Union Address 2016: Towards a better Europe - a Europe that protects, empowers and defends. Retrieved on December 10, 2018 from http://europa.eu/rapid/press-release_SPEECH-16-3043_en.htm

Commission, European (2017a) White Paper on the Future of Europe, Reflections and scenarios for the EU27 by 2025. Retrieved December 10, 2018 from https://ec.europa.eu/commission/sites/betapolitical/files/white paper on the future of europe en.pdf

Commission, European (2017b) EU Citizenship Report: Commission promotes rights, values and democracy. Retrieved December 18, 2018 from http://europa.eu/rapid/pressrelease_IP-17-118_en.htm

Commission, European (2018) Standard Eurobarometer 89, European Citizenship. Retrieved December 12 from http://ec.europa.eu/commfrontoffice/publicopinion/index.cfm/ResultDoc/download/D ocumentKy/83538

Communities, European (1975) European Union, Report by Mr Leo Tindemans, Prime Minister of Belgium, to the European Council. Retrieved December 4, 2018 from https://www.cvce.eu/content/publication/1997/10/13/03f0d181-4838-4a86-a1b5-

\section{f143bb34cbd0/publishable en.pdf}


Communities, European (1983) Solemn Declaration on European Union. Retrieved

December 4 from http://aei.pitt.edu/1788/1/stuttgart declaration 1983.pdf

Communities, Commission of the European (1985) Reports from the ad hoc Committee on a People's Europe, Supplement 7/85. Retrieved on December 1, 2018 from https://core.ac.uk/download/pdf/148840545.pdf

Communities, European (1997) Treaty of Amsterdam. Retrieved on December 3, 2018 from http://www.europarl.europa.eu/topics/treaty/pdf/amst-en.pdf

Cram, L. (2009). Identity and European integration: Diversity as a source of integration. Nations and Nationalism, 15(1), 109-128. doi:10.1111/j.1469-8129.2009.00367.

Della Sala, V. (2016). Europe's odyssey? Political myth and the European union. Nations and Nationalism, 22(3), 524-541. doi:10.1111/nana.12159

Democracy, EU Foundations for (2009) The Lisbon Treaty, third edition. Retrieved December 4, 2018, from http://en.euabc.com/upload/books/lisbon-treaty-3edition.pdf

Dellavalle, S. (2017). "Top-down" vs. "Bottom-up": A dichotomy of paradigms for the legitimation of public power in the EU.Perspectives on Federalism, 9(2), 46. doi:10.1515/pof-2017-0008

Dorril, S. (2007). Blackshirt: Sir Oswald Mosley and British Fascism. London: Penguin.

Duchêne, F. (1994). Jean Monnet : The first statesman of interdependence. New York: Norton. 
European Task Force on Culture, and Development. (1997). In From the Margins : A contribution to the debate on culture and development in Europe. Strasbourg: Strasbourg : Council of Europe.

European Union (2019) About the EU. Retrieved on February $1^{\text {st }}, 2019$ from https://europa.eu/european-union/about-eu_en

Ewing, K. D. (2015). The death of social Europe. King's Law Journal, 26(1), 76-98. doi:10.1080/09615768.2015.1035125

Fromage, D. B., \& van den Brink, T. (2018). Democratic legitimation of EU economic governance challenges and opportunities for European legislatures. Journal of European Integration, 40(3), 235-9511. doi:10.1080/07036337.2018.1450407

Graziano, P., \& Vink, M. P. (2008). Europeanization: new research agendas. London: Palgrave Macmillan. doi:10.1057/9780230584525

Guerrina, R. (2002). Europe: History, ideas and ideologies. London: Arnold.

Guibernau, M. (2011). The birth of a united Europe: On why the EU has generated a 'nonemotional' identity: The birth of a united Europe. Nations and Nationalism, 17(2), 302315. doi:10.1111/j.1469-8129.2010.00477.x

Haas, E. B. (1958). The Uniting of Europe: Political, social, and economic forces 1950 - 1957. London: Stevens.

Holland, M. (1994). European Integration : From community to union. London: Pinter. 
Jović, D. (2009). Yugoslavia : A state that withered away. West Lafayette, Ind.: Purdue University Press.

Judt, T. (2007). Postwar: A History of Europe since 1945. London: Pimlico.

Littoz-Monnet, A. (2012). Agenda-setting dynamics at the EU level: The case of the EU cultural policy. Journal of European Integration, 34(5), 505-522. doi:10.1080/07036337.2011.638065

Majone, G. (2002). Regulating Europe. London: Routledge.

Mazzoni, D., Albanesi, C., Ferreira, P. D., Opermann, S., Pavlopoulos, V., \& Cicognani, E. (2018). Cross-border Mobility, European identity and participation among European adolescents and young adults. European Journal of Developmental Psychology, 15(3), 324-339. doi:10.1080/17405629.2017.1378089

McCormick, J. (2010). Europeanism. Oxford: Oxford University Press.

Milward, A. (1999). The European Rescue of the Nation State (2nd; 2nd ed.). Florence: Routledge Ltd. doi:10.4324/9780203982150

Olsen, J. P. (2002). The Many Faces of Europeanization. JCMS: Journal of Common Market Studies, 40(5), 921-952. doi:10.1111/1468-5965.00403

Sassatelli, M. (2008). European Cultural Space and European Cities Of Culture: Europeanization and cultural policy. European Societies, 10(2), 225-245. doi:10.1080/14616690701835311 
Scott-Smith, G. (2003) Cultural Policy and Citizenship in the European Union: An Answer to the Legitimation Problem? in Cafruny, A. W., and Ryner, M. (2003). A Ruined Fortress? Neoliberal hegemony and transformation in Europe. US: Rowman \& Littlefield.

Seeleib-Kaiser, M. (2018) Citizenship, Europe and Social Rights in Seubert, S., ed. (2018). Moving beyond barriers : Prospects for EU citizenship. Cheltenham: Edward Elgar, 158178.

Sergio, D. (2017). "Top-down” vs. "Bottom-up": A dichotomy of paradigms for the legitimation of public power in the EU. Perspectives on Federalism, 9(2), 46. doi:10.1515/pof-2017-0008

Shore, C. (2000). Building Europe: The cultural politics of European integration. London: Routledge.

Shore, C. (2011). 'European Governance' or Governmentality? The European Commission and the future of democratic government. European Law Journal, 17(3), 287-303. doi:10.1111/j.1468-0386.2011.00551

Shore, C. (2012). The Euro crisis and European Citizenship: The Euro 2001-2012 celebration or commemoration? Anthropology Today, 28(2), 5-9. doi:10.1111/j.14678322.2012 .00859

Shotter, J. (2018) Poland tense over independence rallies, Financial Times, 10 Nov. Retrieved December 19 from https://www.ft.com/content/f7ab4cf8-e385-11e8-8e705e22a430c1ad 
Smith, A. D. (1992). National identity and the Idea of European Unity. International Affairs 1944-1995, 68(1), 55. doi:10.2307/2620461

Smith, A. D. (1993). A Europe of Nations or the Nation of Europe? Journal of Peace Research, 30(2), 129-135. doi:10.1177/0022343393030002001

Spiering, M. (1999). The Future of National Identity in the European Union. National Identities, 1(2), 151-159. doi:10.1080/14608944.1999.9728108

Thatcher, Foundation. n.d. Speech to the College of Europe ('The Bruges Speech'). Retrieved on December 3, 2018 from https://www.margaretthatcher.org/document/107332

Theiler, T. (2005). Political Symbolism and European Integration. Manchester: Manchester University Press.

Vanke, J. (2007). The Treaty of Rome and Europeanism. Journal of the Historical Society, 7(4), 443-474. doi:10.1111/j.1540-5923.2007.00226.x

Wellings, B., \& Power, B. (2015). Euro-myth: Nationalism, war and the legitimacy of the European union. National Identities, 18(2), 157-177. doi:10.1080/14608944.2015.1011110

\section{Endnotes}

'. The figures are higher for Europe than the EU, but not dramatically so. The 2018 Eurobarometer (Commission, 2018, p. 5) finds that $56 \%$ of Europeans said they feel attached to the EU, whilst $65 \%$ said they feel attached to Europe.

ii. Neither article cites the most direct attempt to consider European identity by an authority on nationalism, i.e. Anthony Smith (1992 and 1993). 
iii. There are, of course, limits to the opposition of right-wing governments to the EU. The government of Viktor Orban in Hungary has been vociferous in its criticism of Brussels, but happy enough to take EU monies.

iv. The tensions existed amongst the founding fathers from the 1950s on. Towards the end of his life, Spinelli (in Burgess, 2000, p.14) declared, 'Monnet has the great merit of building Europe and the great responsibility of having built it badly'. But it is not as if there is one Monnet as scholars disagree over the extent to which he was an avowed federalist - for and against see Burgess (2000) and Duchêne (1994)

${ }^{v}$. Shore does not consider the interesting issue (Barker 2001, p. 64) of whether Commission officials were really engaged in self-justification, rather than appealing to Europe's wider public.

vi. Everybody knows that travel does not necessarily soften national proclivities. During a trip to Budapest in December 2016, I sat next to a Brit checking the UKIP webpage in the waiting room of a clinic, whilst my partner saw a German trained Hungarian dentist. Later that day, I listened to my country men and women complain about immigrants at the hotel bar, a conversation that probably would not have taken place a year earlier. 